\title{
Cleavage Reactions of the Complex Ions Derived from Self-Complementary Deoxydinucleotides and Alkali-Metal Ions Using Positive Ion Electrospray Ionization with Tandem Mass Spectrometry
}

\author{
Yun Xiang and Zeper Abliz \\ Beijing, China \\ Mitsuo Takayama \\ Graduate School of Sciences, Yokohama City University, Yokohama, Japan
}

Institute of Materia Medica, Chinese Academy of Medical Sciences and Peking Union Medical College,

\begin{abstract}
The dissociation reactions of the adduct ions derived from the four self-complementary deoxydinucleotides, $\mathrm{d}(\mathrm{ApT}), \mathrm{d}(\mathrm{TpA}), \mathrm{d}(\mathrm{CpG}), \mathrm{d}(\mathrm{GpC})$, and alkali-metal ions were studied in detail by positive ion electrospray ionization multiple-stage mass spectrometry (ESI-MS ${ }^{n}$ ). For the $[\mathrm{M}+\mathrm{H}]^{+}$ions of the four deoxydinucleotides, elimination of $5^{\prime}$-terminus base or loss of both of $5^{\prime}$-terminus base and a deoxyribose were the major dissociation pathway. The ESI-MS ${ }^{n}$ spectra showed that $\mathrm{Li}^{+}, \mathrm{Na}^{+}$, and $\mathrm{Cs}^{+}$bind to deoxydinucleotides mainly by substituting the $\mathrm{H}^{+}$of phosphate group, and these alkali-metal ions preferred to bind to pyrimidine bases rather than purine bases. For a given deoxydinucleotide, the dissociation pathway of $[\mathrm{M}+\mathrm{K}]^{+}$ ions differed clearly from that of $[\mathrm{M}+\mathrm{Li}]^{+},[\mathrm{M}+\mathrm{Na}]^{+}$, and $[\mathrm{M}+\mathrm{Cs}]^{+}$ions. Some interesting and characteristic cleavage reactions were observed in the product-ion spectra of $[\mathrm{M}+\mathrm{K}]^{+}$ ions, including direct elimination of deoxyribose and $\mathrm{HPO}_{3}$ from molecular ions. The fragmentation behavior of the $[\mathrm{M}+\mathrm{K}]^{+}$and $[\mathrm{M}+\mathrm{W}]^{+}(\mathrm{W}=\mathrm{Li}, \mathrm{Na}, \mathrm{Cs})$ adduct ions depend upon the sequence of bases, the interaction between alkali-metal ions and nucleobases, and the steric hindrance caused by bases. (J Am Soc Mass Spectrom 2004, 15, 689-696) (C) 2004 American Society for Mass Spectrometry
\end{abstract}

$\mathrm{T}$ he interaction between organic compounds or biologically active molecules and alkali-metal cations in the gas phase has attracted much attention. Such interactions may relate to chemical and biological processes occurring in solution; for example, ion salvation, catalysis, transport through membranes, affinity of active compounds toward receptors, and antibiotic activity [1]. The alkali metal ions, especially $\mathrm{Na}^{+}$and $\mathrm{K}^{+}$, are of particular importance in the mechanism of action of some biomolecules. Alkali-metal ion affinities are a good basis for analysis and modeling of such interactions in complex systems. The affinities of alkali-metal ions with nucleobases have been investigated by both the kinetic method and threshold collision-induced dissociation mass spectrometry $[2,3]$. On the basis of the research work on the formation of gas-phase ion-molecule complexes, Fujii [4] concluded

Published online February 27, 2004

Address reprint requests to Dr. Z. Abliz, Chinese Academy of Medical Sciences and Peking Union Medical College, 1 Xian Nong Tan Street, Beijing 100050, China. E-mail: zeper@imm.ac.cn that the alkali-metal ion affinity generally followed the order of $\mathrm{Li}^{+}>\mathrm{Na}^{+}>\mathrm{K}^{+}$.

Various mass spectrometric methods have been used to characterize metal ion biomolecular interaction at the molecular level, to determine the site of metal ion attachment to the biomolecular and its effect on altering the properties and reactivities of the biomolecule [1-17]. ESI-MS was shown to be an excellent means for characterizing of oligonucleotides [18, 19], and provide unambiguous identification of singly and multiplycharged ions of deprotonated, protonated, and metalated oligonucleotides.

Knowledge of the fundamental modes of metal ion binding to simple DNA and RNA compounds will greatly improve our understanding of how metal ions interact with nucleic acids of more complexity. Deoxydinucleotides are the smallest subunits in nucleic acids bearing sequence information of DNA.

The dissociation reactions of protonated molecular ions from 12 possible hetero- deoxyribonucleotides were previously studied using fast atom bombardment with tandem mass spectrometry $[5,6]$. It was proposed 


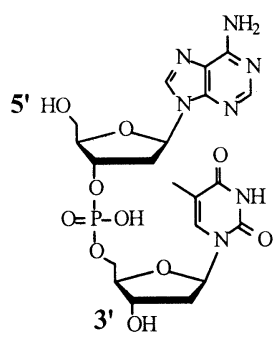

d(ApT)

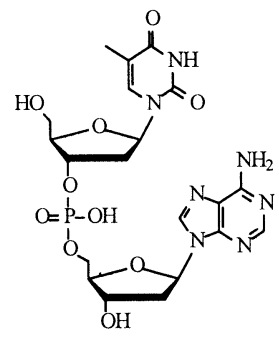

d(TpA)

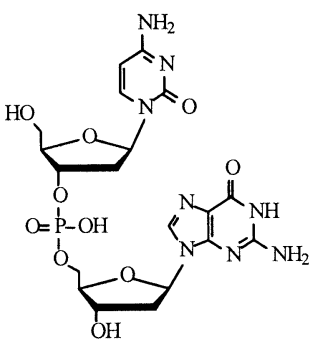

d(CpG)

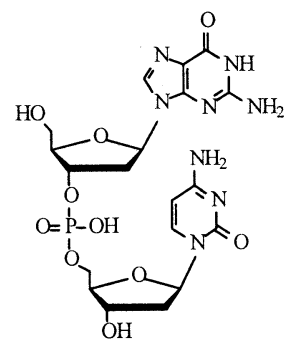

$\mathrm{d}(\mathrm{GpC})$

Scheme 1. Structures of self-complementary deoxydinucleotides.

that dissociation reactions of positive ions are influenced by a tertiary structure in which the phosphate oxygens, stabilized by interactions with the $3^{\prime}$-terminus base. Recently, we studied the fragmentation behavior of oligonucleotides by positive ion ESI-MS and ESIMS/MS [20-22]. In order to investigate the difference of the interaction between alkali-metal ions and deoxydinucleotides with the same bases but different sequence, the cleavage reactions of the complex ions of self-complementary deoxydinucleotides, $\mathrm{d}(\mathrm{ApT})$, $\mathrm{d}(\mathrm{TpA}), \mathrm{d}(\mathrm{CpG})$ and $\mathrm{d}(\mathrm{GpC})$, with $\mathrm{H}^{+}, \mathrm{Li}^{+}, \mathrm{Na}^{+}, \mathrm{K}^{+}$, and $\mathrm{Cs}^{+}$were examined in detail by positive ion ESI-MS ${ }^{\mathrm{n}}$. The structures of these compounds are shown
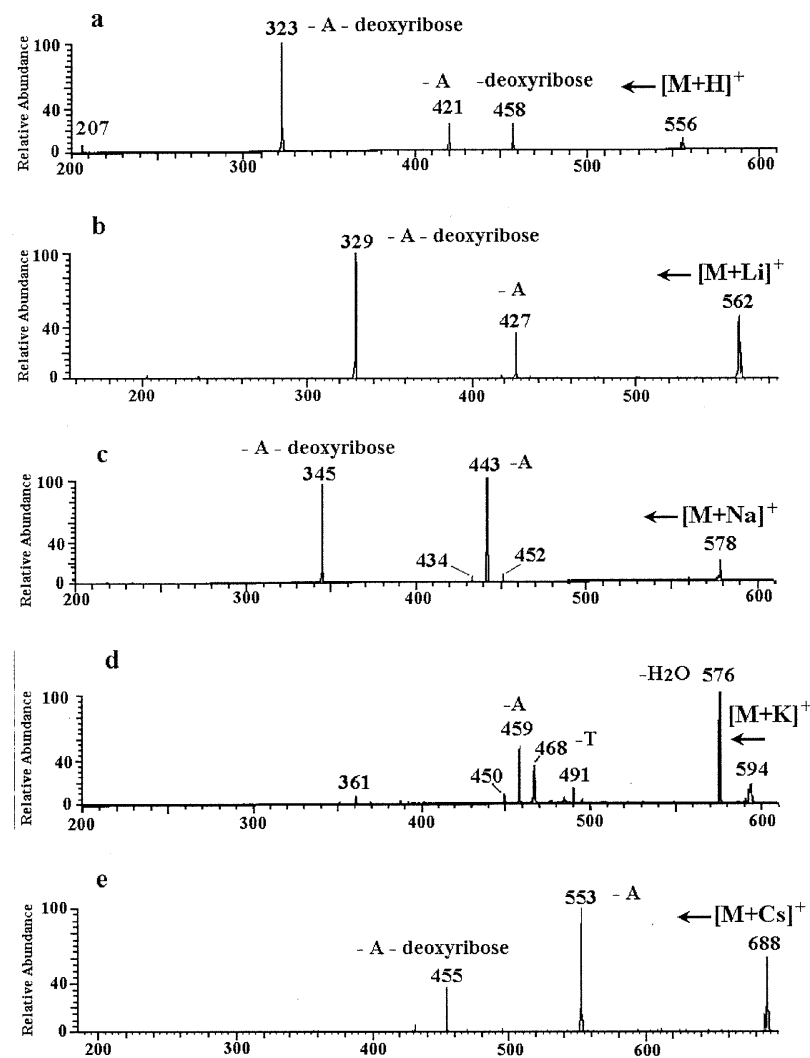

Figure 1. Product-ion spectra of (a) $[\mathrm{M}+\mathrm{H}]^{+}$at $m / z 556$, (b) $[\mathrm{M}$ $+\mathrm{Li}^{+}$at $m / z 562$, (c) $[\mathrm{M}+\mathrm{Na}]^{+}$at $m / z 578,\left(\right.$ d) $[\mathrm{M}+\mathrm{K}]^{+}$at $m / z$ 594 , and (e) $[\mathrm{M}+\mathrm{Cs}]^{+}$ions at $m / z 688$ derived from $\mathrm{d}(\mathrm{ApT})$. in Scheme 1. The characterization and the difference of the cleavage reactions of $[\mathrm{M}+\mathrm{H}]^{+},[\mathrm{M}+\mathrm{Li}]^{+},[\mathrm{M}+$ $\mathrm{Na}]^{+},[\mathrm{M}+\mathrm{K}]^{+}$, and $[\mathrm{M}+\mathrm{Cs}]^{+}$ions were obtained using collision-induced dissociation (CID) analysis with multiple-stage mass spectrometry.

\section{Experimental}

The deoxydinucleotide samples were synthesized using an Applied Biosystems 391s DNA Synthesizer, and were presented by Dr. Takayama from Yokohama City University. The samples were prepared and diluted to
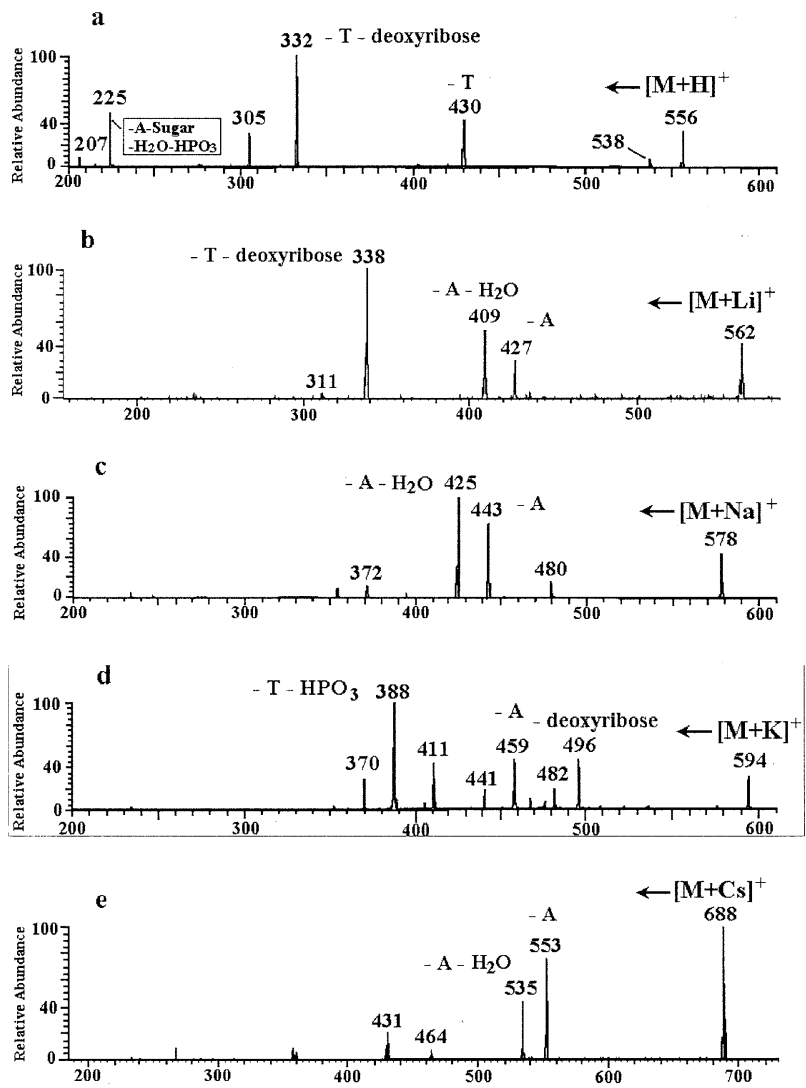

Figure 2. Product-ion spectra of (a) $[\mathrm{M}+\mathrm{H}]^{+}$at $m / z 556$, (b) $[\mathrm{M}$ $+\mathrm{Li}^{+}$at $m / z 562$, (c) $[\mathrm{M}+\mathrm{Na}]^{+}$at $m / z 578$, (d) $[\mathrm{M}+\mathrm{K}]^{+}$at $m / z$ 594 , and $(\mathbf{e})[\mathrm{M}+\mathrm{Cs}]^{+}$ions at $\mathrm{m} / \mathrm{z} 688$ derived from $\mathrm{d}(\mathrm{TpA})$. 

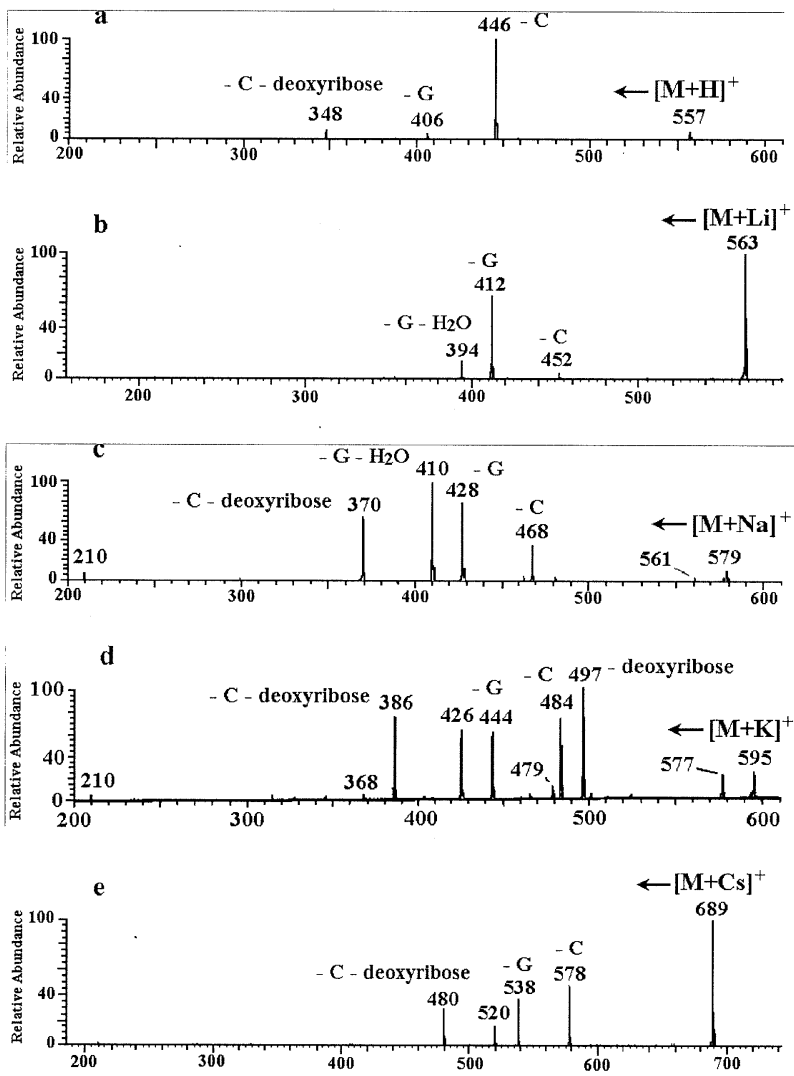

Figure 3. Product-ion spectra of (a) $[\mathrm{M}+\mathrm{H}]^{+}$at $m / z 557$, (b) $[\mathrm{M}$ $+\mathrm{Li}^{+}$at $m / z 563$, (c) $[\mathrm{M}+\mathrm{Na}]^{+}$at $m / z 579$, (d) $[\mathrm{M}+\mathrm{K}]^{+}$at $m / z$ 595 , and $(\mathbf{e})[\mathrm{M}+\mathrm{Cs}]^{+}$ions at $\mathrm{m} / z 689$ derived from $\mathrm{d}(\mathrm{CpG})$.

$10 \mathrm{pmol} / \mu \mathrm{L}$ in a solution of $1 \% \mathrm{CH}_{3} \mathrm{COOH}$ in $50 / 50$ $\mathrm{CH}_{3} \mathrm{CN} / \mathrm{H}_{2} \mathrm{O}$. The solution with the same solvent was used as the mobile phase which was delivered at a flow rate of $5-10 \mu \mathrm{L} / \mathrm{min}$.

The experiments were performed on an ion-trap mass spectrometer (Finnigan LCQ, San Jose, CA), equipped with an ESI source and operated in the positive-ion mode as follows: spray voltage, $5.00 \mathrm{kV}$; capillary voltage, $7 \mathrm{~V}$; heated capillary temperature, 200 ${ }^{\circ} \mathrm{C}$; tube lens offset voltage, $30 \mathrm{~V}$; sheath gas $\left(\mathrm{N}_{2}\right)$ flow rate: 35 arb (roughly $0.75 \mathrm{~L} / \mathrm{min}$ ). The CID spectra were obtained in the presence of a collision gas of He with the relative collision energies varying from 12 to $40 \%$. (Nominal CID amplitude values in this instrument range from $0 \%$ to $100 \%$ relative collision energy corresponding to $0-5 \mathrm{~V}$ zero-to-peak resonant excitation potential).

\section{Results and Discussion}

In the ESI mass spectra of the four self-complementary deoxydinucleotides, besides $[\mathrm{M}+\mathrm{H}]^{+}$ions (base peak), the metal ion adducts, $[\mathrm{M}+\mathrm{Na}]^{+}$and $[\mathrm{M}+\mathrm{K}]^{+}$can also be observed. The solutions of $\mathrm{LiCl}$ and CsI were mixed in the same volume with the $60 \mathrm{pmol} / \mu \mathrm{L}$ deoxydinucleotides in the solution of $1 \% \mathrm{CH}_{3} \mathrm{COOH}$ in $50 / 50$ $\mathrm{CH}_{3} \mathrm{CN} / \mathrm{H}_{2} \mathrm{O}$, and when sprayed, this solution pro-
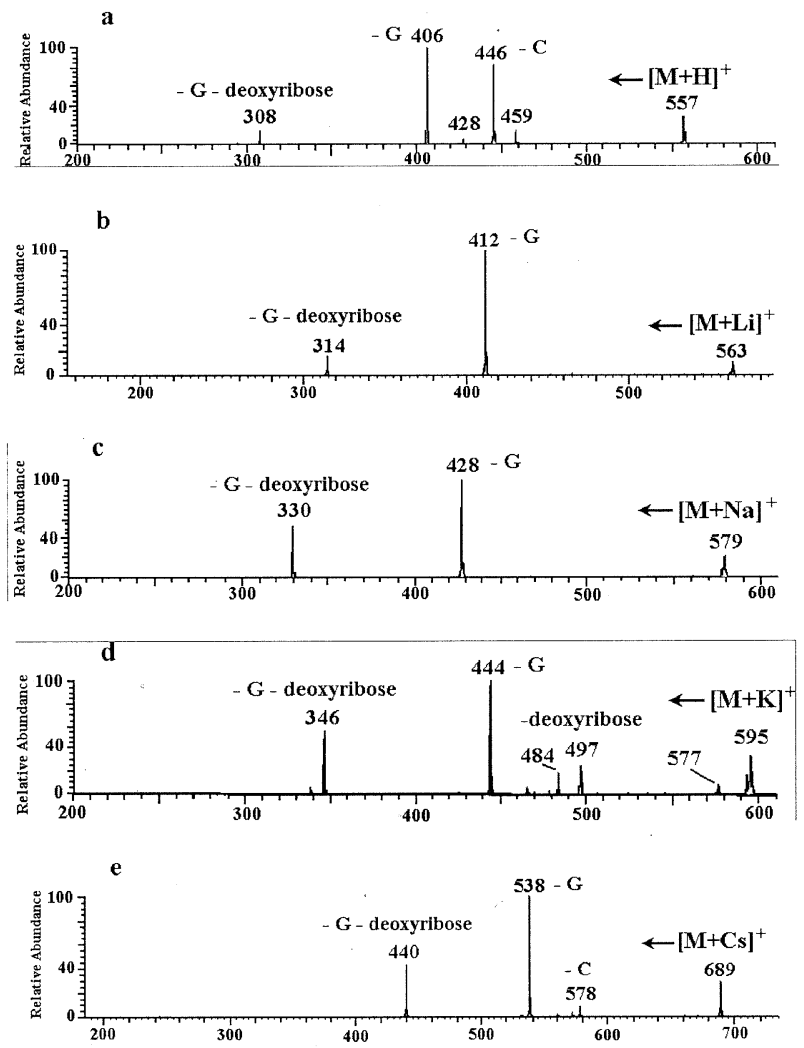

Figure 4. Product-ion spectra of (a) $[\mathrm{M}+\mathrm{H}]^{+}$at $m / z 557,(\mathbf{b})[\mathrm{M}$ $+\mathrm{Li}]^{+}$at $m / z 563$, (c) $[\mathrm{M}+\mathrm{Na}]^{+}$at $m / z 579,(\mathbf{d})[\mathrm{M}+\mathrm{K}]^{+}$at $m / z$ 595 , and (e) $[\mathrm{M}+\mathrm{Cs}]^{+}$ions at $\mathrm{m} / \mathrm{z} 689$ derived from $\mathrm{d}(\mathrm{GpC})$.

duced $[\mathrm{M}+\mathrm{Li}]^{+}$and $[\mathrm{M}+\mathrm{Cs}]^{+}$ions. $[\mathrm{M}+\mathrm{Li}]^{+}$could be observed (base peak) for all of the four deoxydinucleotides, while only $\mathrm{d}(\mathrm{ApT})$ could produce $[\mathrm{M}+$ $\mathrm{Cs}]^{+}$with low abundance $(4.0 \%)$ when both of $\mathrm{Li}^{+}$and $\mathrm{Cs}^{+}$ions are at the concentration of $10 \mathrm{pmol} / \mu \mathrm{L}$. The concentration of $\mathrm{Cs}^{+}$had to be increased by 6-60 times to produce $[\mathrm{M}+\mathrm{Cs}]^{+}$ions for $\mathrm{d}(\mathrm{TpA}), \mathrm{d}(\mathrm{CpG})$, and $\mathrm{d}(\mathrm{GpC})$, but the relative abundances of $[\mathrm{M}+\mathrm{Cs}]^{+}$ derived from them were still very weak. A greater concentration of $\mathrm{Cs}^{+}$was required to produce $[\mathrm{M}+$ $\mathrm{Cs}]^{+}$ions when the $3^{\prime}$-end of deoxydinucleotide was a purine base.

The product-ion spectra of $[\mathrm{M}+\mathrm{H}]^{+},[\mathrm{M}+\mathrm{K}]^{+}$, and $[\mathrm{M}+\mathrm{W}]^{+}(\mathrm{W}=\mathrm{Li}, \mathrm{Na}, \mathrm{Cs})$ ions derived from $\mathrm{d}(\mathrm{ApT})$, $d(\mathrm{TpA}), d(\mathrm{CpG})$, and $d(\mathrm{GpC})$ are shown in Figures 1, 2, 3 , and 4 , respectively. $[\mathrm{M}+\mathrm{K}]^{+}$and $[\mathrm{M}+\mathrm{W}]^{+}$ions may come from coordinative, multisite binding between the metal cations and several cation-accepting groups such as hydroxyl and/or phosphate groups. For the $[\mathrm{M}+\mathrm{H}]^{+}$ions of the four deoxydinucleotides, the major product ions result from loss of $5^{\prime}$-terminus base as neutral molecules (denoted as A, C, T, G) or elimination of both of the $5^{\prime}$-terminus base and a deoxyribose.

As shown in Figure 1a, the major product ions of [M $+\mathrm{H}]^{+}$derived from $\mathrm{d}(\mathrm{ApT})$ are $[\mathrm{M}+\mathrm{H}-\mathrm{A}-$

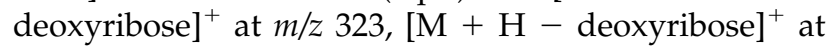



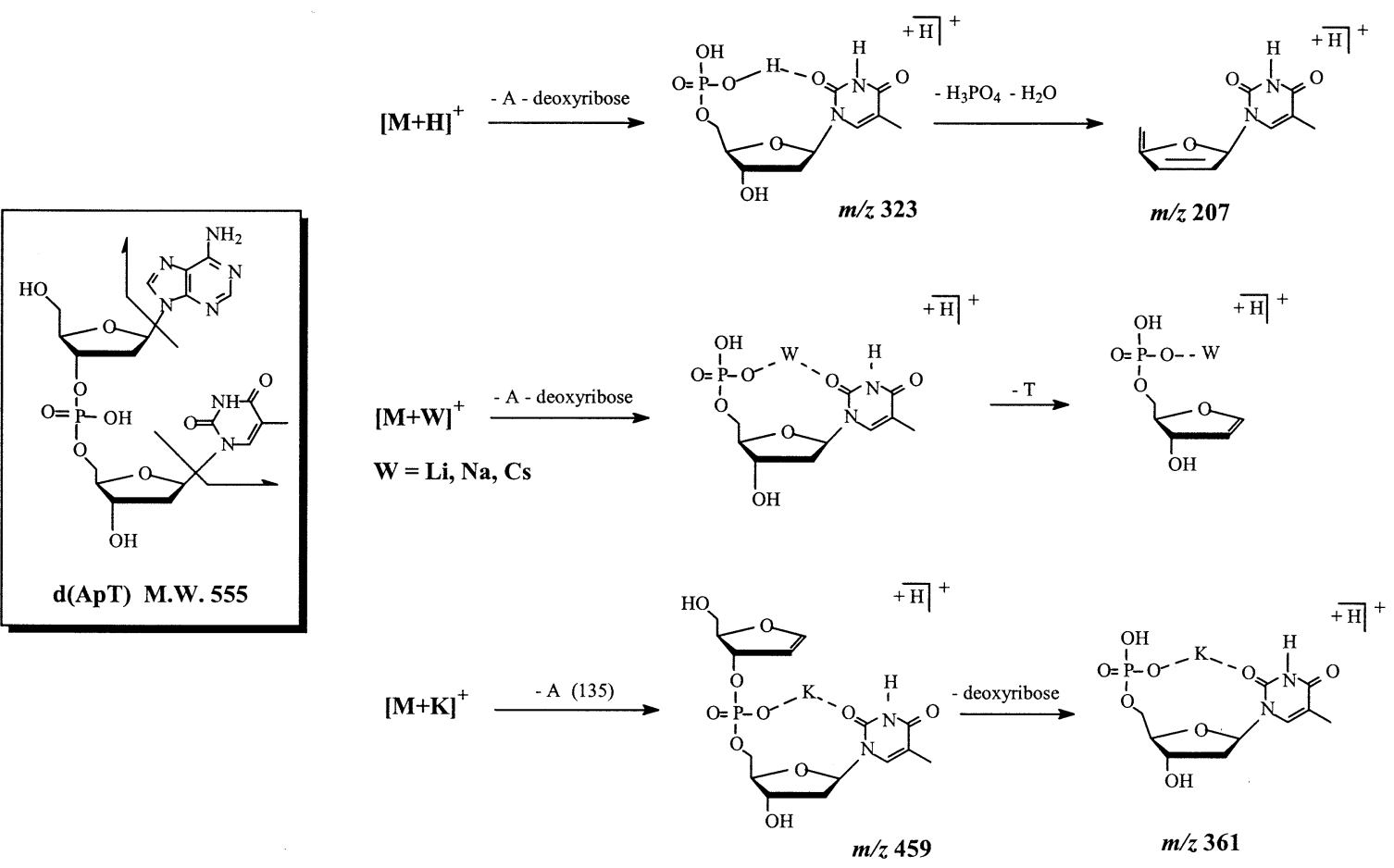

Scheme 2. The main difference in fragmentation of $[\mathrm{M}+\mathrm{H}]^{+},[\mathrm{M}+\mathrm{Li}]^{+},[\mathrm{M}+\mathrm{Na}]^{+},[\mathrm{M}+\mathrm{K}]^{+}$, and $[\mathrm{M}+\mathrm{Cs}]^{+}$proposed to account for the CID spectra of $\mathrm{d}(\mathrm{ApT})$.

$m / z 458$ and $[\mathrm{M}+\mathrm{H}-\mathrm{A}]^{+}$at $m / z 421$. The product-ion spectrum of $\mathrm{m} / \mathrm{z} 323$ (MS ${ }^{3}$ mode) was measured to reconfirm the cleavage reaction of $\mathrm{d}(\mathrm{ApT})$, and the major product ions are $[\mathrm{M}+\mathrm{H}-\mathrm{A}-$ deoxyribose $\left.\mathrm{H}_{3} \mathrm{PO}_{4}-\mathrm{H}_{2} \mathrm{O}\right]^{+}$at $\mathrm{m} / \mathrm{z} 207$ and $[\mathrm{M}+\mathrm{H}-\mathrm{A}-$ deoxyribose $-\mathrm{T}]^{+}$at $m / z 197$.

For $\mathrm{d}(\mathrm{TpA})$, the product ions of the $[\mathrm{M}+\mathrm{H}]^{+}$ precursor consist of $[\mathrm{M}+\mathrm{H}-\mathrm{T}-\text { deoxyribose }]^{+}$at $m / z$ 332, of the highest abundance, $[\mathrm{M}+\mathrm{H}-\mathrm{T}]^{+}$at $\mathrm{m} / \mathrm{z} 430$, $\left[\mathrm{M}+\mathrm{H}-\mathrm{A}-\text { deoxyribose }-\mathrm{H}_{2} \mathrm{O}\right]^{+}$at $m / z 305$ and [M $+\mathrm{H}-\mathrm{A}-$ deoxyribose $\left.-\mathrm{H}_{2} \mathrm{O}-\mathrm{HPO}_{3}\right]^{+}$at $m / z 225$ (see Figure 2a). In the product-ion spectrum of $\mathrm{m} / \mathrm{z} 332$ $\left(\mathrm{MS}^{3}\right.$ mode), the major product ion is $[\mathrm{A}+\mathrm{H}]^{+}$at $\mathrm{m} / \mathrm{z}$ 136.

Figure 3a shows the product ion spectrum of $[\mathrm{M}+$ $\mathrm{H}]^{+}$ion derived from $\mathrm{d}(\mathrm{CpG})$, in which $[\mathrm{M}+\mathrm{H}-\mathrm{C}]^{+}$ at $m / z 446$ is observed to be the major product ion, and

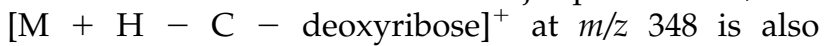
produced. In the product-ion spectrum of the ion of $\mathrm{m} / \mathrm{z}$ 446 ( $\mathrm{MS}^{3}$ mode), the major product ions are $[\mathrm{M}+\mathrm{H}-$ $\mathrm{C}$ - deoxyribose $]^{+}$at $m / z 348$ and $[\mathrm{G}+\mathrm{H}]^{+}$at $m / z 152$.

In the product-ion spectrum of $[\mathrm{M}+\mathrm{H}]^{+}$ion of $\mathrm{d}(\mathrm{GpC})$, the major product ions are $\left[\mathrm{M}+\mathrm{H}-\mathrm{G}^{+}\right.$at $\mathrm{m} / \mathrm{z} 406$, which is the most abundant ion, and $[\mathrm{M}+\mathrm{H}-$ $\mathrm{G}-$ deoxyribose $]^{+}$at $m / z$ 308. Differently from $\mathrm{d}(\mathrm{ApT})$, $d(T p A)$, and $d(C p G), d(G p C)$ can also lose $3^{\prime}$-terminus base to produce $[\mathrm{M}+\mathrm{H}-\mathrm{C}]^{+}$ion at $m / z 446$ with high abundance (see Figure 4a). In the product-ion spectrum of the precursor ion $[\mathrm{M}+\mathrm{H}-\mathrm{G}]^{+}\left(\mathrm{MS}^{3}\right.$ mode), the

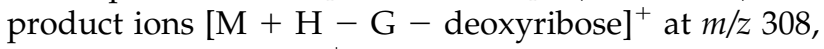
$\left[\mathrm{M}+\mathrm{H}-\mathrm{G}-\mathrm{H}_{2} \mathrm{O}\right]^{+}$at $\mathrm{m} / \mathrm{z} 388$ can be observed.
The major product ions formed in the protonated dinucleotides systems are those resulted from loss of 5 '-terminus base and a deoxyribose. The preferential elimination of the $5^{\prime}$-terminus base over similar bases at $3^{\prime}$-terminus, and the easier cleavage of the $3^{\prime}$-phosphate diester linkage over the $5^{\prime}$-linkage, suggest that the 3 '-terminus base might be stabilized through hydrogen bonding interactions with phosphate group.

Based on the analysis of the product-ion spectra of $[\mathrm{M}+\mathrm{W}]^{+}$, we can find that, although the loss of the terminal bases remained as the major decomposition, the fragmentation behaviors of $[\mathrm{M}+\mathrm{W}]^{+}$differed from that of the $[\mathrm{M}+\mathrm{H}]^{+}$ions. The results suggest that the pyrimidine bases are stabilized when the deoxydinucleotides combined with $\mathrm{Li}^{+}, \mathrm{Na}^{+}$and $\mathrm{Cs}^{+}$.

Figure $1 \mathrm{~b}, \mathrm{c}$, and e show the product-ion spectra of $[\mathrm{M}+\mathrm{Li}]^{+},[\mathrm{M}+\mathrm{Na}]^{+}$, and $[\mathrm{M}+\mathrm{Cs}]^{+}$derived from $\mathrm{d}(\mathrm{ApT})$. Similar to those of $[\mathrm{M}+\mathrm{H}]^{+}$, the major product ions are $[\mathrm{M}+\mathrm{W}-\mathrm{A}]^{+}$and $[\mathrm{M}+\mathrm{W}-\mathrm{A}-$ deoxyribose $]^{+}$, which resulted from loss of $5^{\prime}$-terminus adenine, and both the $\mathrm{A}$ and a deoxyribose. For [M + $\mathrm{H}]^{+},[\mathrm{M}+\mathrm{H}-\mathrm{A}-\text { deoxyribose }]^{+}$is the most abundant product ion, while $[\mathrm{M}+\mathrm{Na}-\mathrm{A}]^{+}$and $[\mathrm{M}+\mathrm{Cs}-$ $\mathrm{Al}^{+}$are the most abundant in the product-ion spectra of $[\mathrm{M}+\mathrm{Na}]^{+}$and $[\mathrm{M}+\mathrm{Cs}]^{+}$, indicating that the fragmentation varied regularly from $[\mathrm{M}+\mathrm{Li}]^{+}$to $[\mathrm{M}+\mathrm{Cs}]^{+}$. The product-ion spectra of $[\mathrm{M}+\mathrm{W}-\mathrm{A}-$ deoxyribose $^{+}$ions show the different cleavage of $[\mathrm{M}+\mathrm{W}]^{+}$ ions from the $[\mathrm{M}+\mathrm{H}]^{+}$ion. It was observed that the major product ions were $[\mathrm{M}+\mathrm{W}-\mathrm{A}-$ deoxyribose $\mathrm{T}]^{+}$and $\left[\mathrm{M}+\mathrm{W}-\mathrm{A}-\text { deoxyribose }-\mathrm{T}-\mathrm{H}_{2} \mathrm{O}\right]^{+}$. 


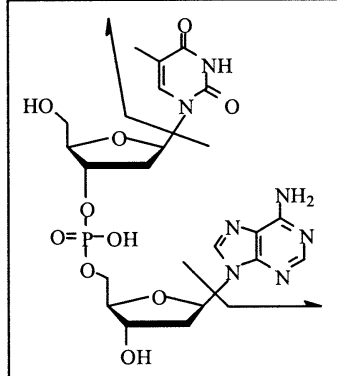

d(TpA) M.W. 555
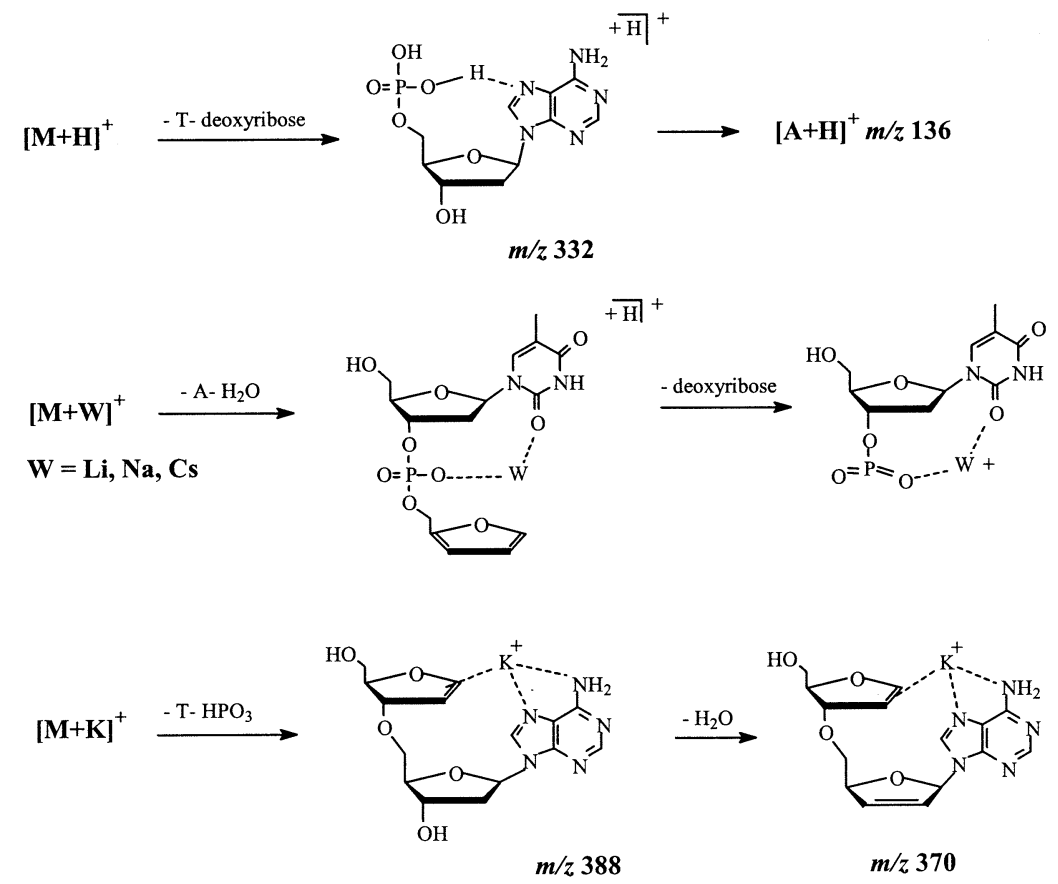

Scheme 3. The main differences in fragmentation of $[\mathrm{M}+\mathrm{H}]^{+},[\mathrm{M}+\mathrm{Li}]^{+},[\mathrm{M}+\mathrm{Na}]^{+},[\mathrm{M}+\mathrm{K}]^{+}$, and $[\mathrm{M}+\mathrm{Cs}]^{+}$proposed to account for the CID spectra of $\mathrm{d}(\mathrm{TpA})$.

For $\mathrm{d}(\mathrm{TpA})$, the presence of the most abundant ions $[\mathrm{M}+\mathrm{W}-\mathrm{A}]^{+}$and $\left[\mathrm{M}+\mathrm{W}-\mathrm{A}-\mathrm{H}_{2} \mathrm{O}\right]^{+}$indicates that the fragmentation of $[\mathrm{M}+\mathrm{W}]^{+}$ions is characteristically dominated by the loss of $3^{\prime}$-terminus $\mathrm{A}$ or both of the A and $\mathrm{a}_{2} \mathrm{O}$ molecule (see Figure $2 \mathrm{~b}, \mathrm{c}$, and e). It is noteworthy that the product ions resulting from loss of 5 '-terminus thymine can not be observed. In the product-ion spectrum of $\left[\mathrm{M}+\mathrm{Li}^{+}\right.$ion, the peak corre-

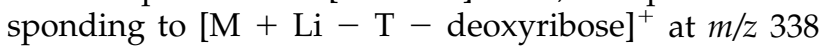
can be observed with the highest abundance. The major product ions of $[\mathrm{M}+\mathrm{Li}-\mathrm{T}-\text { deoxyribose }]^{+}$are $[\mathrm{M}+$ $\mathrm{Li}-\mathrm{T}-$ deoxyribose $-\mathrm{A}^{+}$and $[\mathrm{M}+\mathrm{Li}-\mathrm{T}-$ deoxyribose $\left.-\mathrm{A}-\mathrm{H}_{2} \mathrm{O}\right]^{+}\left(\mathrm{MS}^{3}\right.$ mode). In the production spectrum of $\left[\mathrm{M}+\mathrm{Na}-\mathrm{A}-\mathrm{H}_{2} \mathrm{O}\right]^{+}$ion ( $\mathrm{MS}^{3}$ mode), elimination of a deoxyribose to produce $[\mathrm{M}+\mathrm{Na}-\mathrm{A}$ - $\mathrm{H}_{2} \mathrm{O}$ - deoxyribose ${ }^{+}$ion at $\mathrm{m} / \mathrm{z} 327$ is a major cleavage reaction. The interesting results show that $\mathrm{Li}^{+}$, $\mathrm{Na}^{+}, \mathrm{Cs}^{+}$preferred to bind to thymine rather than adenine.

For $\mathrm{d}(\mathrm{CpG})$, the product-ion spectra of $[\mathrm{M}+\mathrm{W}]^{+}$ ions differ from $[\mathrm{M}+\mathrm{H}]^{+}$ion as shown in Figure 3. In addition to $\left[\mathrm{M}+\mathrm{W}-\mathrm{C}^{+}\right.$and $[\mathrm{M}+\mathrm{W}-\mathrm{C}-$ deoxyribose $]^{+}$, ions resulting from loss of $3^{\prime}$-terminus $\mathrm{G}$ or both the $\mathrm{G}$ and $\mathrm{H}_{2} \mathrm{O}$ are also formed, and the abundance of $[\mathrm{M}+\mathrm{W}-\mathrm{C}]^{+}$ion decreases clearly compared with that of $[\mathrm{M}+\mathrm{H}-\mathrm{C}]^{+}$.

The major product ions of $[\mathrm{M}+\mathrm{W}]^{+}$are very similar for $d(G p C)$, in which the $5^{\prime}$-terminus $G$ is the most favorable for expulsion, and the abundance of $[\mathrm{M}+\mathrm{W}$ - $\mathrm{G}$ - deoxyribose $]^{+}$ion increases. Unlike the $[\mathrm{M}+$ $\mathrm{H}]^{+}$, eliminating cytosine become difficult, which can not be seen in the product-ion spectra of $\left[\mathrm{M}+\mathrm{Li}^{+}\right.$and $[\mathrm{M}+\mathrm{Na}]^{+}$(see Figure 4 ).
To investigate the difference of $d(C p G)$ and $d(G p C)$, we analyzed the product-ion spectra of $[\mathrm{M}+\mathrm{W}-\mathrm{G}]^{+}$ ion (MS ${ }^{3}$ mode) derived from both deoxydinucleotides. For $\mathrm{d}(\mathrm{CpG})$, the major product ions observed were $[\mathrm{M}$ $\left.+\mathrm{Li}-\mathrm{G}-\mathrm{H}_{2} \mathrm{O}\right]^{+},\left[\mathrm{M}+\mathrm{Na}-\mathrm{G}-\mathrm{H}_{2} \mathrm{O}\right]^{+}$and $[\mathrm{M}+$

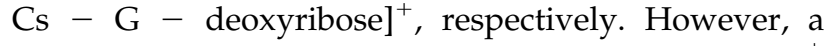
deoxyribose was eliminated from the $[\mathrm{M}+\mathrm{W}-\mathrm{G}]^{+}$ ion derived from $\mathrm{d}(\mathrm{GpC})$ to produce $[\mathrm{M}+\mathrm{W}-\mathrm{G}-$ deoxyribose $]^{+}$.

Based on the analysis of the product-ion spectra of $[\mathrm{M}+\mathrm{W}]^{+}$ions of the four self- complementary deoxydinucleotides, it appears that when deoxydinucleotides bind with $\mathrm{Li}^{+}, \mathrm{Na}^{+}$or $\mathrm{Cs}^{+}$ions, elimination of pyrimide bases become difficult, while loss of purine bases is the dominating step for initial fragmentation, and often followed by elimination of a deoxyribose or $\mathrm{H}_{2} \mathrm{O}$. The facts mentioned above also indicate that $\mathrm{Li}^{+}, \mathrm{Na}^{+}$and $\mathrm{Cs}^{+}$attach to deoxydinucleotides mainly by substituting for the $\mathrm{H}^{+}$of phosphate group, and they prefer to binding with pyrimidine bases rather than purine bases. It can also be found that when $3^{\prime}$-terminus are pyrimide bases, as in $\mathrm{d}(\mathrm{ApT})$ and $\mathrm{d}(\mathrm{GpC})$, the dissociation pathway of $\left[\mathrm{M}+\mathrm{Li}^{+}\right.$is similar to that of $[\mathrm{M}+$ $\mathrm{Na}]^{+}$. However, when purine bases are at the $3^{\prime}$ terminus, as in $\mathrm{d}(\mathrm{TpA})$ and $\mathrm{d}(\mathrm{CpG})$, the fragmentation of [M $+\mathrm{Li}^{+}$is not completely analogous with both of the fragmentation of $[\mathrm{M}+\mathrm{H}]^{+}$and $[\mathrm{M}+\mathrm{Na}]^{+}$. It appears that the steric hindrance caused by the $3^{\prime}$-terminus purine bases prevent alkali-metal ions from substituting for the $\mathrm{H}$ in phosphate group, and a part of metal ions bind to the $5^{\prime}$-terminus bases.

Significant changes take place in the fragmentation behaviors of the $[\mathrm{M}+\mathrm{K}]^{+}$complex ions, and the 


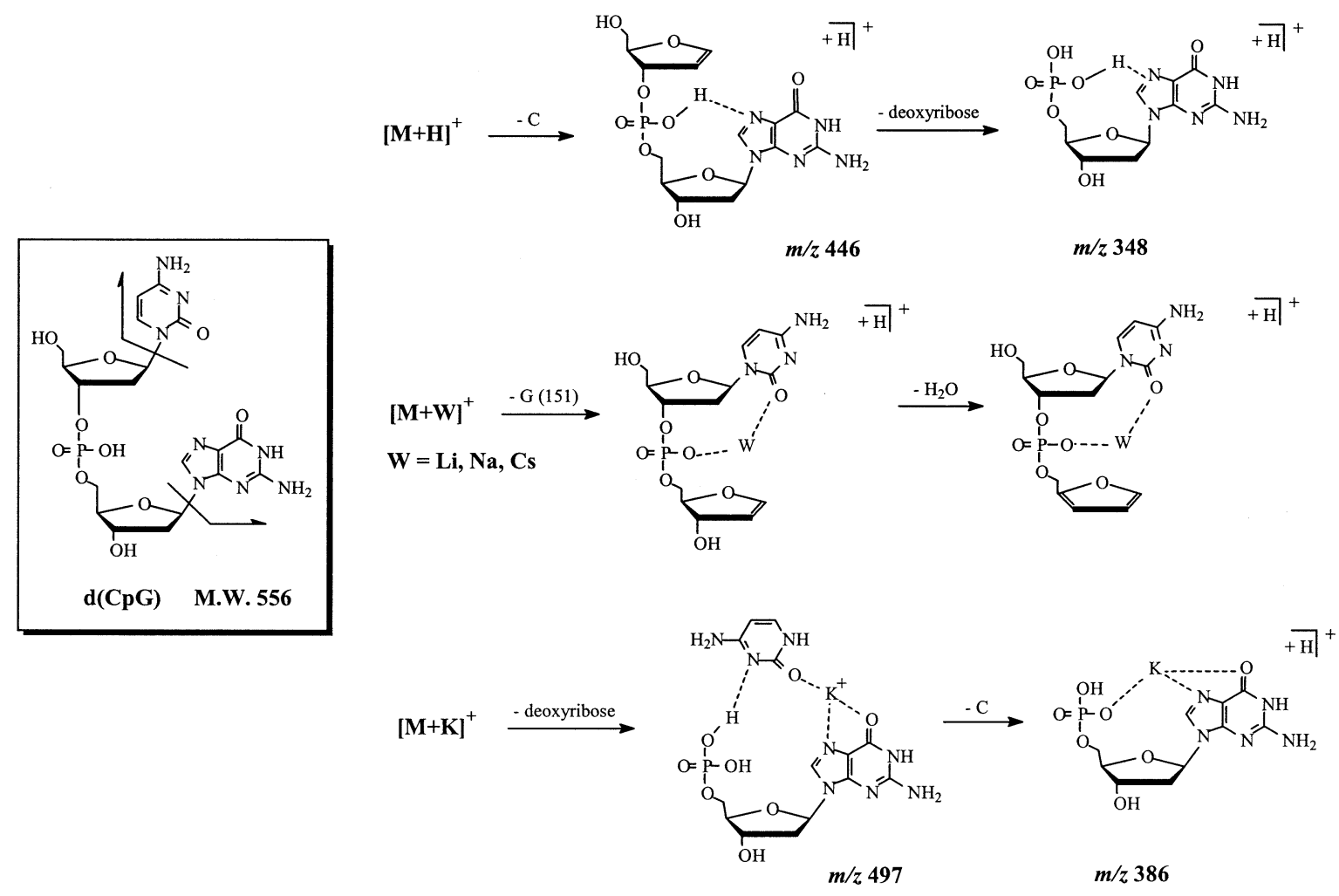

Scheme 4. The main differences in fragmentation of $[\mathrm{M}+\mathrm{H}]^{+},[\mathrm{M}+\mathrm{Li}]^{+},[\mathrm{M}+\mathrm{Na}]^{+},[\mathrm{M}+\mathrm{K}]^{+}$, and $[\mathrm{M}+\mathrm{Cs}]^{+}$proposed to account for the CID spectra of $\mathrm{d}(\mathrm{CpG})$.

characterization of dissociation observed is different for the four deoxydi- nucleotides. The product-ion spectra of $[\mathrm{M}+\mathrm{K}]^{+}$, ( Figure 1d-Figure 4d), show that the cleavage reactions are much more complex in the $[\mathrm{M}+$ $\mathrm{K}^{+}$systems, including not only loss of $5^{\prime}$-terminus bases or a deoxyriboses but also elimination of water, deoxyribose, 3'-terminus base and metaphosphoric acid. The elimination of a deoxyribose or water is more favorable for the $[\mathrm{M}+\mathrm{K}]^{+}$ions than for $[\mathrm{M}+\mathrm{W}]^{+}$.

Comparing the CID spectrum of $\left[\mathrm{M}+\mathrm{K}^{+}\right.$ion of $d(A p T)$ with that of $d(T p A)$, we can see that their fragmentation patterns are quite different. For $\mathrm{d}(\mathrm{ApT})$, the abundance of the $[\mathrm{M}+\mathrm{K}-\mathrm{A}]^{+}$ion at $\mathrm{m} / z 459$ is second highest, only weaker than that of $[\mathrm{M}+\mathrm{K}-$ $\left.\mathrm{H}_{2} \mathrm{O}\right]^{+}$ion at $m / z 576$, and the $[\mathrm{M}+\mathrm{K}-\mathrm{T}]^{+}$ion can also be observed at fairly high abundance. In the production spectrum of $[\mathrm{M}+\mathrm{K}-\mathrm{A}]^{+}\left(\mathrm{MS}^{3}\right.$ mode), the major

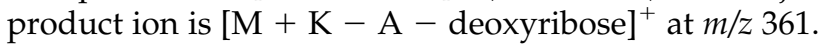
The product-ion spectrum of $[\mathrm{M}+\mathrm{K}]^{+}$derived from $\mathrm{d}(\mathrm{TpA})$ shows that it is more likely to fragment than $\mathrm{d}(\mathrm{ApT})$. The most abundant product ion at $\mathrm{m} / \mathrm{z} 388$ is formed by the loss of a neutral $\mathrm{T}$ and a $\mathrm{HPO}_{3}$ molecule, and the abundance of $[\mathrm{M}+\mathrm{K}-\mathrm{T}]^{+}$decreases clearly. The major product ion of $\left[\mathrm{M}+\mathrm{K}-\mathrm{T}-\mathrm{HPO}_{3}\right]^{+}$at $\mathrm{m} / \mathrm{z}$ 388 is $\left[\mathrm{M}+\mathrm{K}-\mathrm{T}-\mathrm{HPO}_{3}-\mathrm{H}_{2} \mathrm{O}\right]^{+}$at $m / z 370\left(\mathrm{MS}^{3}\right.$ mode). Elimination of an $\mathrm{HPO}_{3}$ molecule is an interesting cleavage reaction, which can also be observed in the product-ion spectrum of $[\mathrm{M}+\mathrm{K}-\mathrm{A}]^{+}$ion at $\mathrm{m} / z 459$ derived from $\mathrm{d}(\mathrm{ApT})$ to produce $[\mathrm{M}+\mathrm{K}-\mathrm{A}-$
$\left.\mathrm{HPO}_{3}\right]^{+}$at $m / z 379$ (MS ${ }^{3}$ mode). Since the radius of $\mathrm{K}^{+}$ ion is greater than that of $\mathrm{Li}^{+}$and $\mathrm{Na}^{+}$, it is more liable for $\mathrm{K}^{+}$to bind with bases and deoxyribose that are located on the exterior surface of the molecule. Schemes 2 and 3 illustrate the main difference in fragmentation of $[\mathrm{M}+\mathrm{H}]^{+},[\mathrm{M}+\mathrm{Li}]^{+},[\mathrm{M}+\mathrm{Na}]^{+},[\mathrm{M}+\mathrm{K}]^{+}$, and $[\mathrm{M}$ $+\mathrm{Cs}]^{+}$ions for $\mathrm{d}(\mathrm{ApT})$ and $\mathrm{d}(\mathrm{TpA})$, respectively.

The product-ion spectrum of $[\mathrm{M}+\mathrm{K}]^{+}$ion of $\mathrm{d}(\mathrm{CpG})$ is more complicated than that of $\mathrm{d}(\mathrm{GpC})$. In addition to $[\mathrm{M}+\mathrm{K}-\mathrm{G}]^{+},\left[\mathrm{M}+\mathrm{K}-\mathrm{G}-\mathrm{H}_{2} \mathrm{O}\right]^{+}$, $[\mathrm{M}$ $+\mathrm{K}-\mathrm{C}]^{+}$and $[\mathrm{M}+\mathrm{K}-\mathrm{C}-\text { deoxyribose }]^{+}$, the $[\mathrm{M}+$ $\mathrm{K}$ - deoxyribose $]^{+}$ion is formed with the highest abundance. In the product-ion spectrum of $[\mathrm{M}+\mathrm{K}-$ deoxyribose $]^{+}$at $\mathrm{m} / \mathrm{z} 497$ (MS $^{3}$ mode), the major product ions are $\left[\mathrm{M}+\mathrm{K}-\text { deoxyribose }-\mathrm{H}_{2} \mathrm{O}\right]^{+}$at $m / z 479$, $[\mathrm{M}+\mathrm{K}-\text { deoxyribose }-\mathrm{C}]^{+}$at $\mathrm{m} / \mathrm{z} 386,[\mathrm{M}+\mathrm{K}-$ deoxyribose $-\mathrm{G}]^{+}$at $\mathrm{m} / \mathrm{z} 346$ and subsequent loss of $\mathrm{H}_{2} \mathrm{O}$. The fragmentation patterns of $\left[\mathrm{M}+\mathrm{K}^{+}\right.$ion derived from $\mathrm{d}(\mathrm{GpC})$ are fairly simple. The main product ions at $\mathrm{m} / \mathrm{z} 444$ and 346 originate from successive loss of $G$ and both of the $G$ base and a deoxyribose, respectively. The $[\mathrm{M}+\mathrm{K}-\text { deoxyribose }]^{+}$ion at $\mathrm{m} / \mathrm{z}$ 497 originates from loss of deoxyribose directly. The major product ions of $[\mathrm{M}+\mathrm{K}-\mathrm{G}]^{+}$at $m / z 444$ MS $^{3}$ mode) are $\left[\mathrm{M}+\mathrm{K}-\mathrm{G}-\mathrm{H}_{2} \mathrm{O}\right]^{+}$at $m / z 426$ and $[\mathrm{M}+$ $\mathrm{K}-\mathrm{G}-$ deoxyribose] $^{+}$at $m / z 346$ (base peak). These results indicate that when $\mathrm{K}^{+}$is attached to a deoxydinucleotide, the sterical exclusion caused by $\mathrm{G}$ is greater than that caused by $\mathrm{C}$. Thus, in the product-ion 


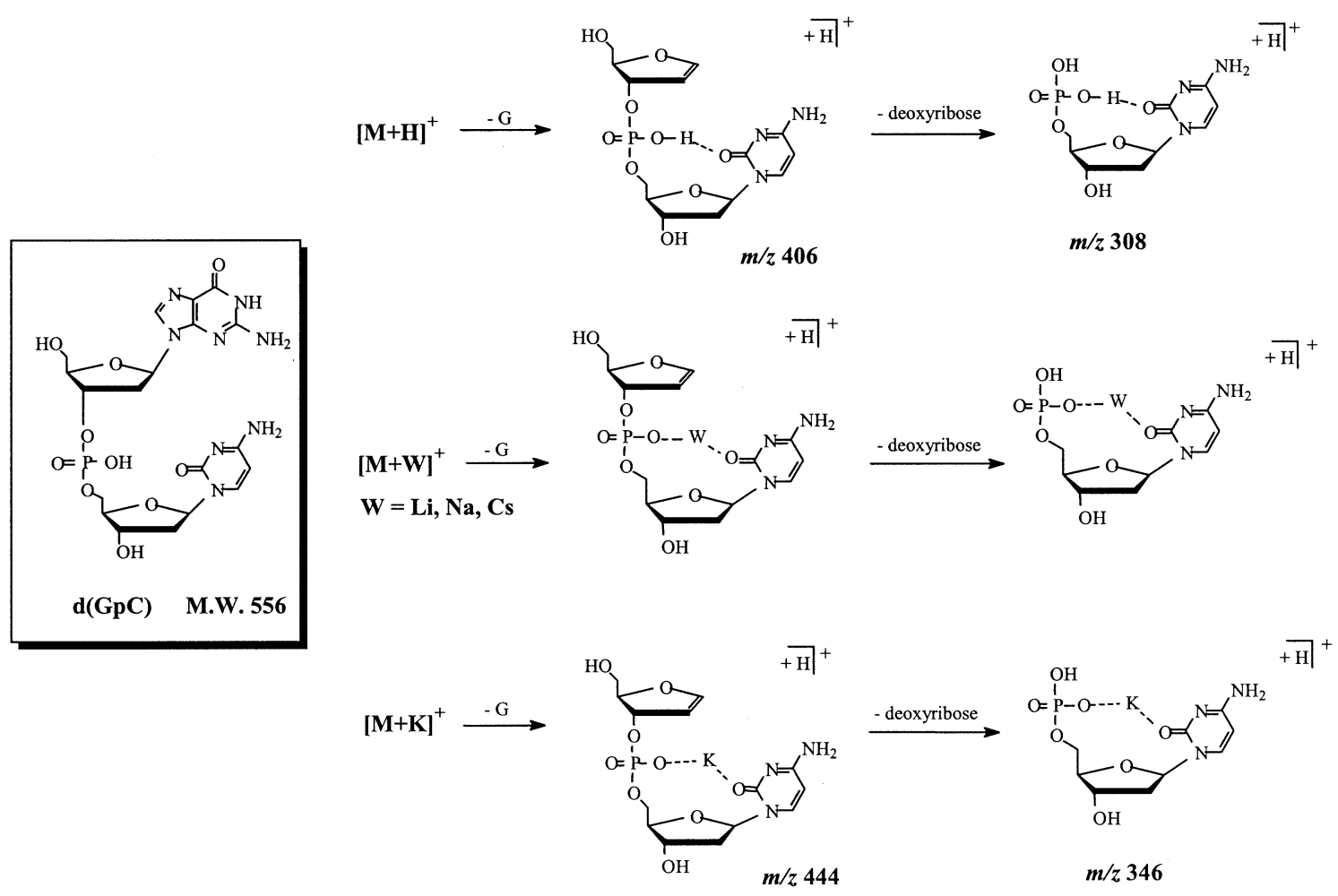

Scheme 5. The main differences in fragmentation of $[\mathrm{M}+\mathrm{H}]^{+},[\mathrm{M}+\mathrm{Li}]^{+},[\mathrm{M}+\mathrm{Na}]^{+},[\mathrm{M}+\mathrm{K}]^{+}$, and $[\mathrm{M}+\mathrm{Cs}]^{+}$proposed to account for the CID spectra of $\mathrm{d}(\mathrm{GpC})$.

spectrum of the $[\mathrm{M}+\mathrm{K}]^{+}$ion derived directly from

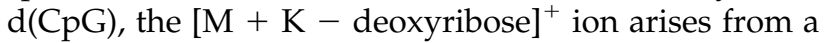
precursor ion in which $\mathrm{K}^{+}$binds to exterior bases of deoxydinucleotides molecules. However, the production spectrum of $[\mathrm{M}+\mathrm{K}]^{+}$ion indicates that $\mathrm{K}^{+}$is easier to bind to the phosphate group in $\mathrm{d}(\mathrm{GpC})$ than in $\mathrm{d}(\mathrm{CpG})$, and the main fragmentation pathway is similar to that of $[\mathrm{M}+\mathrm{Li}]^{+},[\mathrm{M}+\mathrm{Na}]^{+}$and $[\mathrm{M}+\mathrm{Cs}]^{+}$ions. The main differences in fragmentation of $[\mathrm{M}+\mathrm{H}]^{+},[\mathrm{M}$ $+\mathrm{Li}^{+},[\mathrm{M}+\mathrm{Na}]^{+},[\mathrm{M}+\mathrm{K}]^{+}$and $[\mathrm{M}+\mathrm{Cs}]^{+}$ions derived from $\mathrm{d}(\mathrm{CpG})$ and $\mathrm{d}(\mathrm{GpC})$ proposed according to product ion analysis are shown in Schemes $\mathbf{4}$ and 5, respectively.

Based on the analysis of all the product-ion spectra, it appeared that when the $3^{\prime}$-terminus nucleobase is a pyrimidine base, as in $\mathrm{d}(\mathrm{ApT})$ and $\mathrm{d}(\mathrm{GpC})$, the steric exclusion that hinders $\mathrm{K}^{+}$from binding to the phosphate acid is fairly weak. Thus, the fragmentation of the $[\mathrm{M}+\mathrm{K}]^{+}$ion is dominated by the neutral loss of the $5^{\prime}$-terminus nucleobase or both the $5^{\prime}$-terminus base and a deoxyribose. When the $3^{\prime}$-terminus nucleobase is a purine base, as in $\mathrm{d}(\mathrm{TpA})$ and $\mathrm{d}(\mathrm{CpG})$, the larger volume of purine base than that of the pyrimidine base and the correspondingly steric exclusion of purine base is greater than that of pyrimidine base. As the volume of $\mathrm{Li}^{+}$and $\mathrm{Na}^{+}$are smaller than that of $\mathrm{K}^{+}$, the steric exclusion caused by the $3^{\prime}$-terminus purine base did not preclude $\mathrm{Li}$ and $\mathrm{Na}^{+}$from binding to the phosphate, but did hinder $\mathrm{K}^{+}$from binding to the phosphate. $\mathrm{K}^{+}$ attaches to deoxydinucleotides not only by binding to the phosphate group, just as $\mathrm{do}^{+}{ }^{+}$and $\mathrm{Na}^{+}$ions, but also by binding to several other sites (i.e., bases or deoxyribose). Thus, some peculiar cleavage reactions occur for both $\mathrm{d}(\mathrm{TpA})$ and $\mathrm{d}(\mathrm{CpG})$, which have $3^{\prime}$ terminus purine bases. The fragmentation behavior of the $[\mathrm{M}+\mathrm{K}]^{+}$complex ions largely depend upon the sequence of bases, which provid the different binding site for the $\mathrm{K}^{+}$ion in the deoxydinucleotides.

It is noteworthy that the radius of $\mathrm{Cs}^{+}$is greater than that of $\mathrm{K}^{+}$, but the fragmentation behavior of $[\mathrm{M}+\mathrm{Cs}]^{+}$ ions of the four self-complementary deoxydinucleotides is quite different from that of $\left[\mathrm{M}+\mathrm{K}^{+}\right.$but similar to $[\mathrm{M}+\mathrm{Li}]^{+}$and $[\mathrm{M}+\mathrm{Na}]^{+}$. It appears that the volume of $\mathrm{K}^{+}$matches the vacancies between the two bases, so that $\mathrm{K}^{+}$mainly binds to the base groups, resulting in some characteristic fragmentation.

\section{Conclusion}

Results from this study showed that the fragmentation behavior of self-complementary deoxydinucleotides varied markedly due to the differences of the type and the sequence of bases. For $[\mathrm{M}+\mathrm{H}]^{+}$ions of all the four deoxydinucleotides, elimination of $5^{\prime}$-terminus base or loss of both the $5^{\prime}$-terminus base and a deoxyribose are the major dissociation pathways. $\mathrm{Li}^{+}, \mathrm{Na}^{+}$and $\mathrm{Cs}^{+}$ attach to deoxydinucleotides mainly by substituting for the $\mathrm{H}^{+}$of phosphate group, and they prefer to bind with pyrimidine bases rather than purine bases. The fragmentation pathway of $[\mathrm{M}+\mathrm{Li}]^{+}$is similar to that of 
$[\mathrm{M}+\mathrm{Na}]^{+}$for the deoxydinucleotides with $3^{\prime}$-terminus pyrimide bases. However, for deoxydinucleotides with $3^{\prime}$-terminus purine bases, the fragmentation pathway of $[\mathrm{M}+\mathrm{Li}]^{+}$was slightly different from that of $[\mathrm{M}+\mathrm{H}]^{+}$ and $[\mathrm{M}+\mathrm{Na}]^{+}$. In addition to the interaction between alkali-metal ions and nucleobases, 3 '-terminus bases play a more important role in the fragmentation of $[\mathrm{M}$ $+\mathrm{W}^{+}(\mathrm{W}=\mathrm{Li}, \mathrm{Na}$ and $\mathrm{Cs})$ ions than $5^{\prime}$-terminus bases. The fragmentation behavior of the $[\mathrm{M}+\mathrm{K}]^{+}$complex ions largely depend upon the sequence of the bases, the interaction between $\mathrm{K}^{+}$and nucleobases and the steric hindrance caused by bases and $\mathrm{K}^{+}$itself. All of the facts mentioned above lead to different sites for $\mathrm{K}^{+}$ion binding in the deoxydinucleotides.

\section{References}

1. Sannes-Lowery, K. A.; Mack, D. P.; Peifeng, H.; Mei, H.; Loo, J. A. Positive Ion Electrospray Ionization Mass Spectrometry of Oligonucleotides. J. Am. Soc. Mass Spectrom. 1997, 8(1), 90-95.

2. Cerda, B. A.; Wesdemiotis, $\mathrm{C} \mathrm{Li}^{+}, \mathrm{Na}^{+}$, and $\mathrm{K}^{+}$binding to the DNA and RNA Nucleobases. Bond Energies and Attachment Sites from the Dissociation of Metal Ion-Bound Heterodimers. J. Am. Chem. Soc. 1996, 118, 11884-11892.

3. Rodgers, M. T.; Armentrout, P. B. Noncovalent Interactions of Nucleic Acid Bases (Uracil, Thymine, and Adenine) with Alkali Metal Ions. Threshold Collision-Induced Dissociation and Theoretical Studies. J. Am. Chem. Soc. 2000, 122, 85488558.

4. Fujii, T. Alkali-Metal Ion/Molecule Association Reactions and Their Applications to Mass Spectrometry. Mass Spectrom. Rev. 2000, 19, 111-138.

5. Cerny, R. L.; Gross, M. L.; Grotjahn, L. FAB Combined with Tandem MS for Study of Dinucleotides. Anal. Biochem. 1986, 156, 424-435.

6. Phillips, D. R.; McCloskey, J. A. A Comprehensive Study of the Low Energy Collision-Induced Dissociation of Dinucleotide Monophosphates. Int. J. Mass Spectrom. Ion Processes 1993, 128(2), 61-82.

7. Wang, Y.; Taylor, J. S.; Gross, M. L. Fragmentation of Electrospray-Produced Oligodeoxynucleotide Ions Adducted to Metal Ions. J. Am. Soc. Mass Spectrom. 2001, 12(5), 550-556.

8. Hettich, R. L. Formation and Characterization of Iron-Oligonucleotide Complexes with Matrix-Assisted Laser Desorption/Ionization Fourier Transform Ion Cyclotron Resonance Mass Spectrometry. J. Am. Soc. Mass Spectrom. 1999, 10(10), 941-949.

9. Tao, W. A.; Wu, L.; Cooks, R. G. Differentiation and Quantitation of Isomeric Dipeptides by Low-Energy Dissociation of Copper(II)-Bound Complexes. J. Am. Soc. Mass Spectrom. 2001, 12(5), 490-496.
10. Lin, T.; Payne, A. H.; Glish, G. L. Dissociation Pathways of Alkali-Cationized Peptides: Opportunities for C-Terminal Peptide Sequencing. J. Am. Soc. Mass Spectrom. 2001, 12(5), 497-504.

11. Rautenbach, M.; Swart, P.; van der Merwe, M. J. Sequence Specific Stabilization of a Linear Analog of the Antifungal Lipopeptide Iturin $\mathrm{A}_{2}$ by Sodium During Low Energy Electrospray Ionization Mass Spectrometry Conditions. J. Am. Soc. Mass Spectrom. 2001, 12(5), 505-516.

12. Anastassopoulou, J.; Theophanides, T. Magnesium-DNA Interactions and the Possible Relation of Magnesium to Carcinogenesis. Irradiation and Free Radicals. Crit. Rev. Oncol. Hematol. 2002, 42(1), 79-91.

13. Wang, Y.; Taylor, J. S.; Gross, M. L. Fragmentation of Photomodified Oligodeoxy-Nucleotides Adducted with Metal Ions in an Electrospray-Ionization Ion-Trap Mass Spectrometer. J. Am. Soc. Mass Spectrom. 2001, 12(11), 1174-1179.

14. Reyzer, M. L.; Brodbelt, J. S.; Kerwin, S. M.; Kumar, D. Evaluation of Complexation of Metal-Mediated DNA-Binding Drugs to Oligonucleotides via Electrospray Ionization Mass Spectrometry. Nucleic Acids Res. 2001, 29(21), E103.

15. Puapaiboon, U.; Jai-Nhuknan, J.; Cowan, J. A. Characterization of a Multi-Functional Metal-Mediated Nuclease by MALDI-TOF Mass Spectrometry. Nucleic Acids Res. 2001, 29(17), 3652-3656.

16. Hann, S.; Zenker, A.; Galanski, M.; Bereuter, T. L.; Stingeder, G.; Keppler, B. K. HPIC-UV-ICP-SFMS Study of the Interaction of Cisplatin with Guanosine Monophosphate. Fresenius J. Anal. Chem. 2001, 370(5), 581-586.

17. Wu, Q.; Cheng, X.; Hofstadler, S. A.; Smith, R. D. Specific Metal-Oligonucleotide Binding Studied by High Resolution Tandem Mass Spectrometry. J. Mass Spectrom. 1996, 31(6), 669-675.

18. Gentil, E.; Banoub, J. Characterization and Differentiation of Isomeric Self-Complementary DNA Oligomers by Electrospray Tandem Mass Spectrometry. J. Mass Spectrom. 1996, 31(1), 83-94.

19. Ding, J.; Barlow, T.; Dipple, A.; Vouros, P. Separation and Identification of Positively Charged and Neutral Nucleoside Adducts by Capillary Electrochromatography-Microelectrospray Mass Spectrometry. J. Am. Soc. Mass Spectrom. 1998, 9(8), 823-829.

20. Abliz, Z.; Takayama, M.; Xiang, Y.; Li, L. MS/MS Study of Deoxydinucleotides Bound with Alkali-Metal Ions Using ESIMS. Proceedings of the 49th ASMS Conference on Mass Spectrometry and Allied Topics; Chicago, IL, May, 2001;.

21. Abliz, Z.; Takayama, M.; Xiang, Y.; Li, L. MS/MS Study of Deoxydinucleotides Bound with Alkali-Metal Ions Using ESIMS. Chin. Chem. Lett.. 2003, 14(5), 499-502.

22. Xiang, Y.; Abliz, Z.; Li, L.; Takayama, M. Characteristic Fragmentation Behavior of Deoxytetranucleotides by Positive Ion Electrospray Ionization Tandem Mass Spectrometry. Rapid Commun. Mass Spectrom. 2003, 17(11), 1220-1224. 